\title{
AS ASSOCIAÇÕES CIENTÍFICAS DA EDUCAÇÃO E A BASE NACIONAL COMUM CURRICULAR (BNCC) NO CONTEXTO DO SEQUESTRO DA DEMOCRACIA BRASILEIRA
}

\author{
Júlio César Augusto do Valle \\ Universidade de São Paulo - USP
}

\begin{abstract}
Resumo
Desde o início do processo de construção da Base Nacional Comum Curricular (BNCC), as associações científicas da educação - em especial, Associação Nacional de Pós-graduação e Pesquisa em Educação (ANPEd) e Associação Brasileira de Currículo (ABdC) - se fizeram presentes e dispostas ao diálogo, cumprindo seu papel social, imbuído da responsabilidade pública com a educação. Porém, no decorrer desse processo, foram ignorados e permaneceram sem respostas apropriadas os ofícios e as notas sistematizando críticas, dúvidas, indagações e contribuições elaboradas pelas referidas associações, dentre outras, descredibilizando os procedimentos adotados e destituindo-lhe de seu necessário caráter democrático. Nosso propósito neste texto consiste em sistematizar e apresentar os resultados alcançados pela pesquisa qualitativa com ênfase na análise documental desses ofícios e notas elaborados pelas associações científicas. Valemo-nos desses materiais para denunciar, mais uma vez, os graves atentados à democracia brasileira praticados pelos elaboradores e pelo advocacy da BNCC.
\end{abstract}

Palavras-chave: Política curricular, ABdC, ANPEd, BNCC, Currículo.

\begin{abstract}
Since the beginning of the process of building the National Common Curricular Base (BNCC), the scientific associations of education - in particular, the National Graduate Studies and Research in Education Association (ANPEd) and the Brazilian Curriculum Association (ABdC) - have been present and willing to dialogue, fulfilling their social role, imbued with public responsibility for education. However, in the course of this process, the letters and notes were systematically ignored and without appropriate responses, systematizing criticisms, doubts, questions and contributions made by the referred associations, among others, discrediting the procedures adopted and depriving it of its necessary democratic character. Our purpose in this text is to systematize and present the results achieved by qualitative research with an emphasis on documentary analysis of these trades and notes prepared by scientific associations. We use these materials to denounce, once again, the serious attacks on Brazilian democracy practiced by the BNCC's developers and advocacy.
\end{abstract}

Keywords: Curriculum policy, ABdC, ANPEd, BNCC, Curriculum.

ISSN 1645-1384 (online) www.curriculosemfronteiras.org 


\section{Introdução}

Em 2014, o Congresso Nacional aprovou e a presidenta legitimamente eleita Dilma Rousseff (Partido dos Trabalhadores/PT) sancionou o Plano Nacional de Educação (PNE), por meio da Lei Federal 13.005/2014, em que - após muito debate e disputa em torno de concepções de sociedade e de educação bastante divergentes e repletas de especificidades bastante características desse campo de práticas, políticas e pesquisas - o governo federal brasileiro se comprometeu com o atingimento de vinte (20) metas que nos permitiriam avançar em aspectos fundamentais no campo educacional, no período de dez anos (20142024).

As metas representavam princípios garantidores da qualidade pretendida na educação e se traduziram em metas que buscavam garantir maior acesso à educação (especialmente na educação infantil, cujas vagas não suprem a demanda por creche e pré-escola); a permanência na escola (dados os altos índices de evasão escolar durante toda a trajetória escolar de crianças e jovens no Brasil), além dos investimentos em formação inicial e continuada dos professores, valorização do magistério e financiamento público da educação.

Em sua sétima meta, cujo propósito consistia "fomentar a qualidade da educação básica em todas as etapas e modalidades, com melhoria do fluxo escolar e da aprendizagem" de modo a atingir médias nacionais esperadas para o Índice de Desenvolvimento da Educação Básica (IDEB) ${ }^{1}$, o PNE propunha, como primeira estratégia para alcançá-la, um movimento no sentido de "7.1. Estabelecer e implantar, mediante pactuação Inter federativa, diretrizes pedagógicas para a Educação Básica e a base nacional comum dos currículos”.

Desde esse momento, iniciou-se, em âmbito federal, o movimento pactuado no PNE em favor da referida construção, ainda que não houvesse igual comprometimento no alcance de outras metas, inclusive mais relevantes no cenário social e educacional brasileiro, como, por exemplo, as metas relativas à garantia do acesso e da permanência de crianças e jovens na Educação Básica. Porém, no mesmo período de sua construção houve o golpe que destituiu a presidenta eleita Dilma Rousseff e desencadeou uma série de mudanças nos princípios e na maneira de governo, inclusive na agenda de construção da então já esboçada Base Nacional Comum Curricular (BNCC), que, em 2017, teve sua última versão apresentada pelo ministro Mendonça Filho, do governo que substituiu Dilma e o Partido dos Trabalhadores.

Os agentes responsáveis pela advocacy da BNCC sustentaram-se sobre três argumentos, identificados por Cássio (2019, p. 26):

- BNCC como produto de ampla participação social, que coletou 12 milhões de contribuições na consulta pública à primeira versão e outras milhares feitas em audiências públicas regionais/estaduais;

- BNCC como mecanismo promotor de igualdade educacional no Brasil;

- BNCC como auxílio à superação da fragmentação das políticas educacionais, fortalecendo o regime de colaboração entre as três esferas de governo e balizadora da qualidade da educação. 
Houve e ainda há, porém, ampla controvérsia a respeito da argumentação utilizada, de cujo enfrentamento participaram, como protagonistas, a Associação Brasileira de Currículo $(\mathrm{ABdC})$ e a Associação Nacional de Pós-graduação e Pesquisa em Educação (ANPEd), além de outros movimentos sociais e sindicais, que se posicionaram contrariamente à concepção posta em discussão pelo Ministério da Educação (MEC) para a formulação de uma base nacional.

As entidades supramencionadas registram, além das questões que consideram problemáticas ou inconsistentes que identificam na BNCC, que: a) não houve mecanismo de transparência capaz de elucidar como (e mesmo se) foram consideradas as contribuições oriundas da participação social; b) não se verificam os três principais argumentos identificados por Cássio (2019); e c) houve, no decorrer, do processo de elaboração da BNCC uma mudança substantiva de seus princípios orientadores. Posto isso, espera-se, partir do cenário descrito, com este trabalho:

- Resgatar e descrever a trajetória e o contexto de disputas travadas entre o governo federal e as associações científicas da Educação, expressamente representadas, no escopo deste estudo, pela $\mathrm{ABdC}$ e ANPEd, ainda que houvesse outras, como movimentos sociais tais como a Campanha Nacional pelo Direito à Educação;

- Compreender a BNCC enquanto política nacional de centralização curricular e discutir os potenciais reflexos dessa construção diante da diversidade e da desigualdade geográfica, sociocultural e de identidades existentes no Brasil.

Ambos os objetivos descritos buscam responder, de algum modo, à seguinte questão: Como a formulação de uma política nacional do currículo, centralizadora, como a BNCC, pode responder às demandas desiguais e diversas de um país complexo como o Brasil, do ponto de vista educacional, tendo como agravante o fato de terem sido desconsideradas os apontamentos de entidades relevantes para a pesquisa sobre a educação pública brasileira?.

Partimos, portanto, do pressuposto de que uma política nacional de currículo, especialmente em um país culturalmente tão diverso e de proporções continentais como o Brasil, deve levar em consideração: a) toda a diversidade, expressada em oportunidades e contextos de diferença e dissenso; b) a enorme desigualdade que nos caracteriza; c) as diferentes produções de professoras e professores, legítimos praticantes do currículo, cujos saberes-fazeres têm sido sistematicamente negligenciados pelas políticas educacionais brasileiras; d) a abertura ao diálogo com distintas epistemologias e referenciais teóricometodológicos para a prática pedagógica; e e) a autonomia docente, a pluralidade de concepções pedagógicas a gestão democrática, previstas na Lei de Diretrizes e Bases da Educação Nacional (LDB), Lei Federal 9.394/1996 (BRASIL, 1996).

Para isso, tomamos como corpus as notas e os manifestos publicados pelas associações científicas educacionais no decorrer do processo de elaboração e tramitação da Base, por entendê-las, além de legítimas, como subsidiárias e representativas das perspectivas 
ignoradas tanto pelo Ministério da Educação como também pelo Conselho Nacional de Educação, com ênfase no período de 2015 a 2018. Constituem o corpus da investigação, então, os seguintes documentos:

- Ofício n. 01/2015/GR - Exposição de motivos sobre a Base Nacional Comum Curricular (ANPEd \& ABdC, 2015);

- Ofício n. 138/2015 - A Associação Nacional de Pós-Graduação e Pesquisa em Educação e a Base Nacional Comum Curricular (ANPEd, 2015)

- Ofício n. 31/2016 - Aos deputados da Comissão de Educação da Câmara dos Deputados (ANPEd, 2016);

- Nota sobre a entrega da terceira versão da Base Nacional Comum (ANPEd, 2017a);

- Ofício de "Solicitação de respostas às notas das entidades educacionais", coassinado pelas entidades ANFOPE, ANPAE, ABdC, CEDES e FORUMDIR² (ANPEd, 2017b);

- Curricular (BNCC) ao Conselho Nacional de Educação (CNE) Nota "A proposta da BNCC do Ensino Médio: alguns pontos para o debate" (ANPEd, 2018);

- Nota sobre processos de implantação da Base Nacional Comum Curricular do Ensino Fundamental (ABdC, 2018).

A partir do conteúdo crítico e de caráter reivindicador dos documentos elaborados pelas entidades educacionais brasileiras, compostas, em sua maioria, por professores e pesquisadores das universidades públicas brasileiras, argumentaremos no sentido de que a Base Nacional Comum Curricular contribui, enquanto política pública educacional centralizadora e prescritiva, para o sequestro da democracia brasileira.

\section{Aspectos históricos e políticos da formulação da Base Nacional Comum Curriculares}

Para introduzir-nos à compreensão e à crítica do processo de formulação da BNCC, remetemo-nos, primeiro, aos aspectos históricos e políticos que caracterizaram o referido processo. Conforme já mencionado, a busca por uma base nacional comum ${ }^{3}$ tem início, deflagrada como necessidade decorrente da primeira estratégia da Meta 7 do PNE, ainda no governo da presidenta Dilma Rousseff. Naquele momento, as associações científicas educacionais manifestavam expectativas bastante distintas das que viriam a manifestar após a inflexão na condução dessa política, conforme se evidencia no relato das professoras Inês Barbosa de Oliveira - presidenta, à época, da $\mathrm{ABdC}$ - e Maria Luiza Süssekind:

Chefiada por uma colega pesquisadora, a Professora Beatriz Luce, a Secretaria de Educação Básica (SEB) do MEC seria parceira das associações em presença ABdC (Associação Brasileira de Currículo) e ANPEd (Associação Nacional de Pós-graduação e Pesquisa em Educação) - na reflexão sobre o que fazer para assegurar uma política de currículo comprometida com os direitos dos estudantes da escola pública, em sua imensa maioria oriundos de classes sociais desfavorecidas. Também demonstravam preocupação com "os currículos" que já 
existiam e aconteciam nas redes e escolas, que não deveriam ser simplesmente ignorados, mereciam ser considerados. (OLIVEIRA; SÜSSEKIND, 2018, p. 56)

Com efeito, toda e qualquer expectativa de que a política curricular nacional considerasse os currículos praticados, especialmente nas escolas públicas brasileiras, dandolhes cobertura, até mesmo com um "currículo sem fundamentos", nos termos da professora Alice Lopes (2015), se esvaziou com o golpe jurídico-parlamentar que retirou, sem demonstrar as evidências dos crimes fiscais que teria cometido, a presidenta Dilma Rousseff. Para Cury, Reis e Zanardi (2018, p. 77-78), "a ruptura institucional e democrática, ocorrida em 2016, deixa marcas indeléveis nas políticas públicas brasileiras”, de modo que, no contexto educacional, são promovidas "políticas públicas alinhadas com os interesses do capital frente ao sistema educacional público brasileiro (...) [e] a BNCC se situa nesse contexto de medidas e soluções para superação da crise.

Antes disso, porém, ainda em 2015, as tensões acirradas no cenário político e o início do movimento de fragilizar a imagem política da presidenta conduziram-na à modificação substantiva da gestão do MEC. Tais mudanças impactam significativamente, por sua vez, a condução das políticas educacionais, com ênfase na formulação da BNCC, conforme nos conta o registro seguinte:

O Professor Manuel Palácios assumiu a SEB e montou uma equipe de "especialistas" para a elaboração da BNCC, apoiado em um discurso de que a BNCC estaria sendo democraticamente formulada por contar com professores de todos os níveis de ensino e de todas as regiões do país. Omitia em seu discurso o fato de que cada uma das equipes disciplinares, num total de 29, era composta por apenas quatro docentes. Ou seja, a "democraticidade" do conjunto escondia uma fragilidade real de equipes pequenas, trabalhando isoladamente, apenas em torno dos conteúdos de suas respectivas disciplinas. Chamávamos a atenção para o fato de que o debate curricular não estava sendo feito nas escolas, nem com as escolas. (OLIVEIRA; SÜSSEKIND, 2018, p. 57)

O golpe à democracia, por meio do "impeachment" de Dilma Rousseff, acirraria, ainda mais, o referido cenário, retirando-lhe também o caráter democrático. Por esse motivo, argumentamos que, se por um lado, um viés conservador e pouco democrático foi introduzido no processo sob a gestão de Dilma Rousseff; por outro, não é possível compreendê-lo descontextualizando-o do golpe, promotor de uma ruptura da história recente da democracia brasileira. Afinal, a expectativa de que uma pequena comunidade de especialistas possa redigir o texto que busca identificar o que é comum e nacional no Brasil "é tributária de um currículo que desconfia do potencial transformador que o contexto vivido, do diálogo e da problematização como princípios orientadores da construção curricular (CURY; REI; ZANARDI, 2018, p. 87). E foi precisamente nessa direção que avançaram os movimentos de formulação da BNCC, após a inflexão promovida pelo golpe.

Consideramos, também, relevante mencionar, na esteira do que outros pesquisadores vêm afirmando, o fato de que é "impossível compreender a Base sem investigar o cenário 
desenhado pela Organização para Cooperação e Desenvolvimento Econômico (OCDE) que reconhecidamente influencia políticas públicas educacionais brasileiras, como atesta a própria BNCC em seu texto" (CURY; REIS; ZANARDI, 2018, p. 78). Isso porque, ainda que não constitua o propósito deste trabalho, discursos e políticas econômicas globais têm atribuído às reformas educacionais, em especial às políticas de centralização curricular, a capacidade de superar as desigualdades sociais instaladas nos mais diferentes países, conforme sinaliza também Hypolito (2019) no texto em que situa a BNCC como produto desses discursos e políticas.

No contexto do Global Education Reform Moviment (GERM), por exemplo, desde 2001, apresentam-se argumentos favoráveis às reformas educacionais por meio do que consideram ser "a eficácia dos sistemas educacionais", sustentada por três princípios na política educacional: "padrões, prestação de contas e descentralização" (Hypolito, 2019, p. 189). Em termos da padronização, afirma o autor, que "está prescrito um currículo nacional que estabeleça padrões de qualidade, a partir de avaliações nacionais com metas e padrões de aprendizagem alcançáveis". No que se refere à descentralização, "advoga-se a transferência de competências e de responsabilidades para os níveis locais de administração do sistema escolar, de modo que as avaliações nacionais sirvam para responsabilizar e controlar as autoridades em seus diferentes níveis de competência". Já no âmbito da prestação de contas, "os atores educacionais são responsabilizados pelo desempenho/performance por intermédio de avaliações com consequências, o que pretende ser alcançado tanto por uma accountability administrativa, em que os resultados dos exames são vinculados a prêmios ou sanções" (HYPOLITO, 2019, p. 189), cujo propósito consiste no estímulo à competição entre as escolas. Importa-nos, portanto, identificar que:

(...) há uma agenda global que vai se estruturando localmente, a partir de grupos hegemônicos, nem sempre coesos, ora mais liberais, ora mais ultraliberais, ora neoconservadores e autoritários, mas que têm obtido sucesso em impor sua agenda que assume formas múltiplas de atender os ditames do mercado e dos interesses conservadores. A BNCC está no centro desses interesses e, a meu ver, tem servido tanto para aprofundar interesses de mercado como interesses em torno do controle sobre o conhecimento, com as investidas ideológicas conservadoras. (HYPOLITO, 2019, p. 199)

Ainda que autoras como Diane Ravitch (2011) tenham denunciado a ineficácia das chamadas "políticas de endurecer o currículo escolar" - políticas pelas quais a autora não somente advogou, mas também com as quais contribuiu em sua atuação política nos Estados Unidos - a BNCC seguiria, como veremos, sustentada e sustentando a mesma lógica infundada e inconsistente de centralização curricular nos termos definidos pelas políticas globais ${ }^{4}$.

As associações científicas não deixaram de se manifestar no decorrer do processo de formulação da Base, inclusive tensionando os discursos e as políticas globais, cuja transposição irrefletida e acrítica para o cenário brasileiro somente agravaria nossa histórica 
desigualdade social e educacional. Ignorar as principais instituições educacionais e de pesquisa brasileiras, favorecendo o diálogo com os setores privados, reforça, portanto, a lógica mercadológica e a presença dos interesses privados globais nas reformas educacionais. Por isso nosso interesse em destacar o posicionamento das referidas entidades. Afinal, "o caso da BNCC e as associações de pesquisas acadêmicas é um capítulo à parte no seu desenrolar", dado que "as associações, especialmente, da Associação Nacional de Pesquisa em Educação (ANPEd), sempre canalizaram críticas não só ao conteúdo da BNCC, mas à metodologia e à própria concepção de currículo nacional que a BNCC incorpora (CURY, REIS E ZANARDI, 2018, p. 95).

Posto isso, retornamos ao processo de formulação da Base, valendo-nos do registro feito pela educadora Márcia Angela Aguiar (2018), conselheira do Conselho Nacional de Educação, responsável por um dos votos contrários ao documento. Aguiar $(2018$, p. 9) nos informa que, de início, o CNE constituiu uma Comissão Bicameral (criada pela Portaria CNE/CP n. 11/2014), cujo objetivo seria "acompanhar e contribuir com o Ministério da Educação na elaboração de documento acerca dos direitos e objetivos de aprendizagem e desenvolvimento, tendo em vista, principalmente, as estratégias 2.1 e 2.2 da Meta 2 e as estratégias 3.2 e 3.3 da Meta 3 previstas no Plano Nacional de Educação aprovado pela Lei No 13.005, de 25 de junho de 2014". A esse movimento inicial, seguiu, em 2015, o convite para que cerca de cento e vinte (120) profissionais da educação - os "especialistas" mencionados em excerto anterior - para a elaboração da primeira versão do documento, recusando como iniciativa primeira a escuta das educadoras e dos educadores que atuam nas mais distintas realidades educacionais de nosso país.

Essa versão foi colocada em consulta pública, por meio de internet, entre outubro de 2015 e março de 2016. Segundo dados do MEC, houve mais de 12 milhões de contribuições ao texto, com a participação de cerca de 300 mil pessoas e instituições. Contou, também, com pareceres de especialistas brasileiros e estrangeiros, associações científicas e membros da comunidade acadêmica. As contribuições foram sistematizadas por profissionais da Universidade de Brasília (UnB) e da Pontifícia Universidade Católica do Rio de Janeiro (PUC-RJ), e subsidiaram o MEC na elaboração da "segunda versão". (AGUIAR, 2018, p. 11)

Nesse ponto, cumpre-nos dizer que muitos dos argumentos que afirmam o caráter democrático da formulação da Base sustentam-se nos quantitativos apresentados no excerto anterior. Afirmou-se que a ampla participação da sociedade brasileira, por meio das contribuições ao texto, tornava-o produto de uma consulta efetiva não somente da comunidade educacional, como também da sociedade civil de modo mais amplo. Nesse sentido, importa-nos tensionar a referida "virtude democrática do processo de construção da Base", a partir do estudo realizado por Cássio (2019, p. 27):

Desde 2016, o discurso laudatório da BNCC tem se apoiado em uma série de dados que comprovariam as virtudes democráticas do processo de construção da Base, começando pelas incríveis "12 milhões de contribuições" provenientes da 
consulta pública à primeira versão. (...) A análise dos microdados da consulta pública, obtidos via Lei de Acesso à Informação (Lei n. 12.527/2011), mostra que o número total de contribuintes únicos da consulta é 143.928. Logo, entre o número de contribuintes únicos e as 12 milhões de "contribuições" divulgadas há uma diferença de $8400 \%$. Para o MEC, um clique de "concordo" e um comentário crítico com 50 linhas foram igualmente considerados "contribuições". Por isso, 98,48\% das "milhões de contribuições" são constituídas por mais de 11,9 milhões de cliques de resposta aos questionários de múltipla escolha sobre a clareza do texto e a pertinência/relevância dos objetos de aprendizagem. As contribuições efetivas, comentários e sugestões de inclusão e modificação do texto, representam apenas $1,52 \%$ do total de "contribuições".

O referido estudo desmascara o pretensioso caráter democrático da Base brasileira, não somente porque no cenário nacional essa participação de $1,52 \%$ é ínfima, mas também porque todas as contribuições oriundas tanto da consulta pública como das audiências públicas realizadas foram ignoradas na ocasião da proposição da terceira versão do documento, como veremos adiante. Ademais, podemos sublinhar também o fato de que o MEC teve aproximadamente dois meses para leitura, reflexão e sistematização das contribuições provenientes dessa consulta. O que nos permite inferir - especialmente a partir do fato de que nunca foram apresentadas quaisquer sistematizações ou metodologias de leitura/análise dessas contribuições ${ }^{5}$ - que não houve sequer tempo hábil para levá-las em consideração para a estruturação da segunda versão, que foi apresentada em Maio de 2016, segundo a própria plataforma virtual do Ministério ${ }^{6}$.

Nesse momento, foram inclusive apresentadas ao CNE e ao MEC os pontos mais substantivos da crítica construída no âmbito das entidades educacionais ao documento apresentado. Para as pesquisadoras e os pesquisadores responsáveis pela elaboração do Ofício 138/2015, o documento

Não contempla as dimensões de diversidade na educação brasileira, o que coloca em risco de retrocesso toda política educacional e ambiental no país, expressa hoje na Resolução 2/2012 do CNE que estabelece as Diretrizes Curriculares para a Educação Ambiental. Os associados afirmam seu posicionamento contrário à Base Nacional Comum Curricular tanto pela sua metodologia de elaboração quanto às evidentes implicações nos processos de avaliação de ensino aprendizagem, na homogeneização das matrizes curriculares, na formação de professores e na autonomia. (ANPEd, 2015, p. 1)

Ofício respondido meses mais tarde, em 2016, pelo Diretor de Currículos e Educação Integral do MEC, Ítalo Dutra, informando que "as valiosas contribuições da Anped recebidas por esta Diretoria poderão ser inseridas no Portal da Base (...). Esclarecemos, por fim, que as contribuições da Associação serão objeto de apreciação pela Comissão de Especialistas". Tais críticas - ainda que fossem submetidas pelo Portal da Base, onde acontecia a consulta pública, como sugere o interlocutor do Ministério - não seriam consideradas, como sabemos. 
Diante da resposta e da continuidade no desenvolvimento da política curricular nos mesmos moldes em que ocorriam antes da manifestação das associações, representantes das diretorias da ANPEd e da ABdC reuniram-se em fevereiro. Dessa reunião depreendeu-se a criação da campanha nacional "Aqui já tem currículo". Conforme explicaram, "o principal objetivo dessa reunião era dar visibilidade à multiplicidade de práticas docentes que acontecem nas escolas brasileiras, de modo não só a trazer para o debate a 'voz' os educadores da educação básica secundarizados no processo de produção da BNCC” (ANPEd, 2015, p. 3). A campanha "Aqui já tem currículo" buscava, na contramão da Base, "valorizar as experiências curriculares que acontecem nos diferentes cotidianos das escolas e que resistem a muitas possibilidades de uma narrativa hegemônica curricular, como pretende o texto da BNCC" (ANPEd, 2015, p. 4) ${ }^{7}$.

Já a segunda versão do documento, que supostamente incorporou as contribuições anteriores, foi posta em discussão por cerca de nove (9) mil educadores no âmbito de seminários realizados pela União Nacional dos Dirigentes Municipais de Educação (UNDIME) e pelo Conselho Nacional de Secretários de Educação (CONSED), no período de Junho a Agosto de 2016. Sobre tais seminários, acrescenta-se que:

Os 27 seminários estaduais da segunda versão adotaram uma metodologia mais complexa para a coleta das contribuições dos 9.275 representantes das redes de ensino. Utilizando questionários abertos e de múltipla escolha, em diversos turnos, foram coletados comentários e sugestões por componente curricular e por Etapa da Educação Básica. As planilhas de sistematização por estado e o relatóriosíntese das contribuições produzidos por UNDIME e CONSED, mostram um grande número de críticas aos textos introdutórios, mas engajamentos desiguais nas contribuições referentes aos componentes curriculares. A partir dessas contribuições é que teria sido produzida a terceira versão da Base. (CÁSSIO, 2019, p. 28)

A metodologia de análise das participações nos seminários foi estruturada por meio de "discussões em salas específicas, por áreas de estudo/componentes curriculares, e coordenada por moderadores que, em sua maioria, apresentavam slides com objetivos e conteúdos" (AGUIAR, 2018, p. 11). Diante das exposições, os participantes optavam entre as alternativas "concordo", "discordo totalmente" ou "discordo parcialmente", indicando propostas de alteração. Com base nesse movimento, o CONSED e a UNDIME elaboraram um relatório que foi encaminhado ao Comitê Gestor do MEC, responsável, então, pela revisão da segunda versão, a partir dos apontamentos e das contribuições, que daria origem à terceira versão do documento, submetida ao CNE em abril de 2017. Aqui, importa-nos sublinhar o fato de que o documento tratava somente da Educação Infantil e do Ensino Fundamental, "sem a devida argumentação sobre o não atendimento legal ao excluir, dessa versão, o Ensino Médio” (AGUIAR, 2018, p. 11).

Também nesse momento as associações científicas educacionais se manifestaram com respeito à realização dos seminários e às escolhas, não-arbitrárias, mas absolutamente 
questionáveis, de seus participantes, cujos critérios de seleção não respeitaram quaisquer compromissos, inclusive legais, com a transparência.

É, portanto, com extrema preocupação que nossa associação científica recebe a notícia da realização do Seminário sobre a Base Nacional Comum Curricular na Comissão de Educação da Câmara dos Deputados e, em especial, o caráter que nos pareceu enviesado e prosélito na composição da escolha dos convidados. Registramos nesta oportunidade nossa indignação com o privilegiamento de representantes de grupos que tentam cercear a liberdade de cátedra e expressão de professores e professoras nas escolas brasileiras. É inadmissível que debates sobre a educação brasileira, em especial na referida conjuntura social e política nacional, se contraponham aos princípios constitucionais da pluralidade de ideias pedagógicas e ao necessário apreço à tolerância e respeito aos direitos humanos. (ANPEd, 2016, p. 1, grifos nossos)

A menção aos grupos que tentam cercear a liberdade de cátedra e expressão de professoras e professores nas escolas brasileiras faz referência aqui à participação de setores e atores, compondo efetivas alas, do conservadorismo e mesmo do ultraconservadorismo brasileiro, inclinados à caça e à eliminação das palavras "gênero" e "sexualidade" em todo o texto do documento, assim como às tentativas, algumas delas exitosas, de eliminar menções e abordagens das culturas africanas, afro-brasileiras e indígenas. Assumindo-os como interlocutores legítimos a Base perde (ainda mais) sua capacidade de responder à diversidade, à diferença e à desigualdade que nos caracterizam como povo/nação.

A terceira versão da Base, que seria posteriormente aprovada como o documento final, se apresenta, não por acaso, como a mais problemática das três versões, tanto do ponto de vista de sua estrutura como do ponto de vista de seu enredamento com as demais versões. Sobre ela, lemos ainda:

A proposta da terceira versão, diferente das anteriores, já excluía o Ensino Médio e trazia uma ruptura com a ideia de educação básica. O CNE promoveu uma audiência em cada uma das cinco regiões do Brasil de junho a setembro de 2017, da qual participaram entidades, professores e interessados. De setembro a dezembro de 2017, a base nacional comum curricular tramitou no CNE de forma não transparente e foi aprovada desconsiderando a construção já produzida pelas instituições educacionais comprometidas com a educação pública de qualidade social e sob forte resistência de três conselheiras, representantes de entidades nacionais, que votaram contra a $\mathrm{BNCC}$, assim como diversas instituições e associações de docentes e pesquisadores manifestaram sua oposição a BNCC. A aprovação de uma política pública de forma antidemocrática, sem transparência e sem ampla discussão com a sociedade brasileira revela o modus operandi dos sujeitos individuais e coletivos que fazem parte, tanto de instituições consideradas públicas, quanto privadas. (ARELARO; PERONI; CAETANO, 2019, p. 43) 
Sublinhamos, também, o que consideramos outra evidência do descompromisso com os procedimentos democráticos de construção da política curricular na forma como seus próprios elaboradores argumentavam, isto é, a (re)incorporação da pedagogia das competências $^{8}$. A mais flagrante confissão do modus operandi a que se referem as autoras acima está registrada no próprio documento que a UNDIME e o CONSED encaminharam no momento anterior, em que dizem textualmente: "Embora não tenha sido mencionado nos Seminários, o CONSED avalia que o currículo do Ensino Médio deva ser organizado por competências" (Cássio, 2019, p. 29). Com mais essa inflexão, a terceira versão da BNCC brota/surge/aparece com todas as etapas da Educação Básica reorganizadas em torno dessa matriz pedagógica, de fundamentos e propósitos frágeis e inconsistentes. "Diante de tudo isso", afirma Cássio (2019, p. 29), "é provável que os seminários estaduais tenham sido o esforço mais significativo, mas também o mais vão, de construção participativa do texto da BNCC".

Não é possível que se admita algo assim, como uma artimanha, injustificada, em um país que leve a sério suas políticas, especialmente as educacionais, que terão reflexos substantivos na formação humana e social das gerações que se educam nas escolas nos mais distintos contextos nacionais.

No texto final da BNCC, esse processo aparece camuflado por uma justificativa que, além de ter sido construída a posteriori, também não nos parece legítima. Afinal, nos Fundamentos Pedagógicos da Base, escritos em apenas duas páginas - o que é igualmente vexatório e demonstra que não se trata de uma política a ser levada a sério -, lemos que "o foco no desenvolvimento de competências tem orientado a maioria dos Estados e Municípios brasileiros e diferentes países na construção de seus currículos" (BRASIL, 2017, p. 13). Na nota de rodapé, porém, lemos que "segundo a pesquisa elaborada pelo Cenpec, das 16 Unidades da Federação cujos documentos curriculares foram analisados, 10 delas explicitam uma visão de ensino por competências, recorrendo aos termos 'competência' e 'habilidade' (ou equivalentes, como 'capacidade', 'expectativa de aprendizagem' ou 'o que os alunos devem aprender')" (BRASIL, 2017, p. 13, rodapé). Não se pode inferir que a pedagogia das competências tenha orientado "a maioria dos Estados e Municípios brasileiros" na construção de seus currículos, simples e matematicamente porque dez (10) estados não representam a maioria dos estados brasileiros.

A escolha da pedagogia das competências ${ }^{9}$, ademais (como se fosse necessário dizer ainda mais!), representa uma opção político-metodológica que restringe a autonomia docente, com ênfase no inciso III do artigo $3^{\circ}$ da LDB, que assevera que ao ensino deve ser assegurado o "pluralismo de ideias e de concepções pedagógicas". Cabe aqui mencionar, inclusive, a nota em que a $\mathrm{ABdC}$ se manifesta com relação às limitações impostas pelo texto da versão final:

A BNCC não tem o poder de exaurir as disputas no e do campo curricular, lócus privilegiado de disputas no qual diferentes saberes e vivências se colocam frente às prescrições. Por isso, a $\mathrm{ABdC}$ entende que a pretensão de padronização e fixação de identidades e projetos constituem o vício insanável da $\mathrm{BNCC}$ e aposta 
nas possibilidades de negociações para superação dessa proposta centralizadora. Recomendamos a promoção de ações junto aos professores nos diferentes cursos de licenciatura e nas secretarias municipais de educação como estratégia de discussão crítica a este cenário. Entendemos que é momento de intensificar o debate sobre currículos fortalecendo a perspectiva de produção local - na linha da campanha "Aqui já tem currículo" (parceria ANPEd/ABdC) -, a autonomia e a autoria de professores, estudantes e escolas para que assumam o protagonismo em desafio à BNCC. (ABdC, 2018, pp. 1-2)

Embora esse movimento ilegítimo de incorporação seja bastante desagradável para um contexto democrático, não surpreende, contudo, que essa iniciativa tenha sido gestada no âmbito de um processo de formulação autoritário, centralizado e centralizador, limitado, enviesado e antidemocrático que, mais do que a preocupação efetiva em responder aos dispositivos legais que antecederam a Base em termos da política educacional, a concebe como palco em que se apresentam, perfilados um a um, os mais pérfidos interesses privados no âmbito da educação. A pedagogia das competências não passa de mais uma das ferramentas lançadas com vistas ao alcance desses interesses, ainda que seja uma das ferramentas mais temerárias com a finalidade última de controle do exercício do trabalho docente. Nesse sentido, convergimos para a crítica formulada pela $\mathrm{ABdC}$ que se centra sobre o fato de que a terceira versão e, portanto, a própria Base

Não respeita o princípio do pluralismo de ideias e concepções pedagógicas, assumindo uma, e somente uma em sua formulação. Sendo conteudista e disciplinarista, fere o princípio da valorização da experiência extraescolar e a formação para o exercício da cidadania. Investe no controle externo da gestão e do fazer docente, por meio de avaliações externas (de alunos, professores e gestores) aliadas à responsabilização local pelos resultados, comprometendo o princípio da gestão democrática, a formulação participativa do Projeto Pedagógico e o princípio da valorização docente. (ABdC, 2017, p. 2) ${ }^{10}$

A crítica acima se fundamenta, sob nosso ponto de vista, também a partir da preocupação com o fato de ter se intensificado a participação de setores empresariais, privados e conservadores no processo de formulação da BNCC, esvaziando-a de quaisquer pretensões de se caracterizar como produto de um processo democrático, de escuta participativa, coletiva, ainda que os agentes vinculados ao seu advocacy insistam, ainda hoje, na ideia de que não há óbice algum.

Cumpre-nos salientar, inclusive, que momentos antes da aprovação e da homologação da Base, ao fim de 2017, as entidades se manifestaram mais uma vez por meio de um ofício endereçado ao Presidente da Comissão da BNCC no Conselho Nacional de Educação, César Callegari, solicitando respostas às notas e aos ofícios encaminhados anteriormente, cuja desconsideração evidencia ainda mais a ilegitimidade democrática do processo de construção do documento. Neste último ofício, lemos que: 
As entidades educacionais, abaixo nominadas, vêm solicitar resposta sobre as Notas Públicas encaminhadas como contribuições fundamentadas e circunstanciadas ao debate sobre a terceira versão da Base Nacional Comum Curricular (BNCC), por ocasião das diversas Audiências Públicas realizadas em cada região do país, entre julho a setembro do corrente ano. Essas entidades representam educadores/as e de pesquisadores/as segmentos importantes de no campo da educação, que apresentam expectativas de verem consideradas as suas análises e propostas sobre a BNCC, salvaguardando o direito de opinar sobre as diretrizes da educação nacional e reivindicar o debate democrático como princípio de construção dos currículos escolares. (ANPEd, 2017b, p. 1)

Ao mesmo tempo em que solicitavam as devidas respostas, as entidades educacionais, mobilizadas principalmente em torno da ANPEd e da ABdC, mas contendo muitas outras, reivindicavam também a suspensão da tramitação dos processos relativos à Base e, em especial, sua votação, a fim de que a matéria pudesse ser melhor discutida. Parece-nos evidente que o menor senso republicano de construção de uma política pública deveria tomar como imprescindível o direito (e também a necessidade) de participar/opinar/intervir dos educadores e pesquisadores vinculados às associações científicas, sem os quais não se pode assumir o caráter democrático atribuído pretensiosamente à Base. Sem estabelecer o diálogo com educadores e pesquisadores da educação e, com ainda mais ênfase, do campo do currículo, deixando de se manifestar a respeito das notas e dos ofícios encaminhados pelas entidades educacionais, tanto o MEC como também o CNE afirmaram o desprestígio com que compreendem não somente o trabalho realizado por professoras e professores nas milhares de escolas brasileiras, mas também as pesquisas realizadas em diferentes universidades públicas do país.

Negligenciar tais contribuições ${ }^{11}$ afastou qualquer possibilidade de considerar o documento e sua política curricular correlata como tributários de uma "concepção curricular inclusiva, plural e emancipatória, que contribua para a garantia do direito à educação pública, gratuita, laica, democrática, inclusiva e de qualidade socialmente referenciada", como defendiam as entidades (ANPEd, 2017b, p. 2). Porém, não houve resposta satisfatória para esse ou qualquer outro ofício encaminhado ao CNE, como também não foi atendido o pedido de suspensão da votação/tramitação da Base, que foi aprovada em seguida. "Infelizmente, a opção do CNE foi pela celeridade em detrimento de discussão aprofundada, como requer a matéria", afirma uma de suas conselheiras (Aguiar, 2018, p. 20). Esse processo, para a conselheira, que votou contrariamente, "ficará registrado como uma afronta a esse Órgão Colegiado, sobretudo, se o entendermos como um Órgão de Estado e não de Governo".

O processo prossegue, então, com a formulação da Base Nacional Comum Curricular do Ensino Médio (BNCC-EM) que - nunca é demais repetir - não deveria ter sido apartada, para início de conversa, do restante da Educação Básica, comprometendo e desfigurando já de pronto o propósito de enredar suas diferentes etapas e modalidades. O fato de o CNE têlas aceitado e aprovado endossa gravemente a crítica de Aguiar (2018) feita anteriormente de que esse importante órgão colegiado atuou como cúmplice de todas as ilegalidades e 
ilegitimidades praticadas nesse processo. Um exemplo que ilustra essa afirmação pode ser lido a seguir:

As audiências públicas sobre a BNCC do Ensino Médio (...) se mostraram um tanto surpreendentes. A audiência da região Sudeste, realizada em São Paulo/SP (08 jun. 2018), teve o plenário ocupado por professores e secundaristas antes mesmo de ser iniciada. A nota oficial do CNE informou que a audiência fora "cancelada, pois grupos de manifestantes impediram que o tema pudesse ser discutido com a devida profundidade". O CNE não percebeu, mas esta foi a primeira audiência pública da Base em que participaram aqueles que, até então, não haviam sido escutados. A audiência pública da região Norte, realizada em Belém/PA (10 ago. 2018), também teve a mesa ocupada por estudantes, professores, dirigentes sindicais e pesquisadores, que conduziram os trabalhos sem os membros do CNE. (CÁSSIO, 2019, p. 30)

As associações científicas educacionais, como era de se esperar, permaneceram resistindo e se manifestando contra o despudor, ainda mais escancarado, na condução do processo para o Ensino Médio. Em nota oficial, a ANPEd (2018, p. 1) assim se posicionou:

A retirada do ensino médio da proposta da BNCC da Educação Básica já aprovada para a educação infantil e para o ensino médio, foi um fato simbólico, com um significado fundamental para a compreensão da atual reforma por meio da MP746/16 que resultou na Lei 13.415/17. Esta etapa da educação escolar brasileira foi, na prática, desvinculada da Educação Básica, contrariando a LDB/1996, que considera o ensino médio, no interior de uma concepção educacional avançada de educação básica, uma das suas três etapas, indissociável das demais. A cisão da educação básica, com o envio pelo MEC da proposta de BNCC da educação infantil e do ensino fundamental sem o ensino médio, cabe perguntar, foi dialogada com quem? A única versão pública que o MEC apresentou para a BNCC do ensino médio é a que foi entregue ao CNE. Quem tornou público o debate foi o $\mathrm{CNE}$ e por isso podemos afirmar que a atual $\mathrm{BNCC}$ para o Ensino Médio é uma versão piorada, reducionista e autoritária.

É importante elucidar, nesse sentido, que a Lei Federal 13.415/2017, citada acima, também é mencionada no texto da BNCC-EM, na introdução àquilo que chamam de “itinerários formativos" para o Ensino Médio. Nela, lemos:

Na direção de substituir o modelo único de currículo do Ensino Médio por um modelo diversificado e flexível, a Lei $\mathrm{n}^{\circ} 13.415 / 2017$ alterou a LDB, estabelecendo que: $\mathrm{O}$ currículo do ensino médio será composto pela Base Nacional Comum Curricular e por itinerários formativos, que deverão ser organizados por meio da oferta de diferentes arranjos curriculares, conforme a relevância para o contexto local e a possibilidade dos sistemas de ensino, a saber: I - linguagens e suas tecnologias; II - matemática e suas tecnologias; III - ciências 
da natureza e suas tecnologias; IV - ciências humanas e sociais aplicadas; V formação técnica e profissional. (BRASIL, 2017, p. 468)

A Base, porém, também reconhece que, na esteira da legislação mencionada, o detalhamento dos itinerários formativos "é prerrogativa dos diferentes sistemas, redes e escolas" (BRASIL, 2017, p. 469), o que nos faz concordar com a afirmação de que "não há base material que sustente as alterações feitas na LDB ou na BNCC para escolha de trajetórias pelos estudantes" (ANPEd, 2018, p. 5). Afinal, se quem definirá as trajetórias são as condições de oferta dos sistemas, redes e escolas, como estabelece a Lei 13.415/2017, então "isto marcará profundamente o ensino médio como o campo da desigualdade oficial para a juventude brasileira", pois, conforme nota encaminhada pela entidade, "não há garantias de que os sistemas educacionais consigam cumprir com a parte diversificada. A oferta de todos os itinerários formativos certamente não vai acontecer, os alunos não terão a possibilidade da escolha como tem sido anunciado, ficarão restritos às possibilidades de oferta das escolas" (ANPEd, 2018, p. 5).

Assim, reconhecendo que a proposta dos itinerários formativos contribui, em larga medida, para o acirramento das desigualdades que afetam as juventudes brasileiras, o texto enviado pela entidade reivindicava também que:

o CNE precisa reafirmar a existência e vigência das Diretrizes Curriculares para Educação Básica e as Diretrizes Curriculares para o Ensino Médio, já aprovadas por este egrégio Conselho, e que orientam de maneira adequada a formulação das propostas pedagógicas das escolas brasileiras considerando a diversidade e a autonomia necessárias à construção de uma escola que respeite e valorize as juventudes e garanta na escola as possibilidades de pleno desenvolvimento humano contribuindo para a redução das desigualdades em nosso país. (ANPEd, 2018, p. 5)

Não é necessário dizer que, assim como as notas, os ofícios e posicionamentos anteriores, está também foi ignorada e o processo se concluiu como conta um dos excertos anteriores.

Por esses "pecados de origem”, como chamam Oliveira e Süssekind (2018, p. 58) - em especial denotados pelo desrespeito, descrédito e descompromisso com os numerosos posicionamentos e tentativas de contribuir com o debate de constituição da política curricular nacional elaborados pelas entidades educacionais - concordamos enfaticamente com as autoras quando afirmam que "as discussões que ainda hoje se desenvolvem em torno da $\mathrm{BNCC}$, em que se busca pensar em meios de nela intervir para sua melhoria, nos parecem extemporâneas e fadadas ao fracasso". Não somente suas premissas, como sinalizam Oliveira e Süssekind (2018, p. 59), mas também os procedimentos adotados e os interlocutores privilegiados são irreconciliáveis "com a busca de uma educação democrática, pública, laica, gratuita e de qualidade social para todos".

A partir do delineamento desse processo de formulação da Base e instituição da política curricular, discutimos a seguir como esse movimento se insere num contexto mais amplo, da 
política econômica global, recusando o potencial emancipador da educação, ignorando o que afirmam as pesquisas e as práticas educativas em curso, negligenciando a formação crítica das juventudes e, mais gravemente, contribuindo para o sequestro da democracia brasileira.

\section{Políticas educacionais globais e o sequestro da democracia brasileira}

Nunca é demais recordar, portanto, que a Base não somente desconsidera as desigualdades sociais e as diferenças que impactam de diferentes maneiras as juventudes brasileiras, mas também admite como seu papel o enfrentamento das referidas desigualdades, por meio do desenvolvimento das mesmas competências e habilidades em todo território nacional, tornando-se, assim, mais um instrumento que contribui para o seu agravamento.

Sob essa mesma perspectiva, a pesquisadora brasileira do campo do currículo Alice Lopes (2018, p. 25) elucida a pretensão ideológica equivocada que inspira a busca por uma política curricular nacional centralizadora e prescritiva, sob o pretexto de que contribui para a eliminação das desigualdades:

Muitos que defendem a BNCC alegam que sem essa base se desenvolve uma desigualdade no sistema, justamente por existirem diferentes propostas curriculares em ação. Defendo, contudo, que isso não é um erro nem mesmo um problema. A pretensão de que todas as escolas sigam a mesma proposta curricular e a mesma orientação pedagógica com a ideia de que, com isso, as metas de aprendizagem serão garantidas, tende a ocultar a problemática de que a desigualdade social associada à educação não é decorrente de um registro intrinsecamente pedagógico. Se há desigualdades no sistema educativo - e essas desigualdades existem - isso se deve ao investimento diferenciado na carreira do professor e nas condições de trabalho nas escolas, nas condições de vida das famílias e nas condições de estudo dos alunos e alunas.

Como diferentes autores, inclusive referenciais deste trabalho, têm afirmado, imputar à escola e aos seus atores o combate à desigualdade social, por meio da política curricular, delega-lhes também a responsabilidade pelo contínuo fracasso nesse combate, dado que, sem outras políticas públicas sociais que busquem melhor distribuir renda e serviços básicos, a desigualdade somente se aprofunda. Com efeito, remetemo-nos à afirmação de Cury, Reis \& Zanardi (2018, p. 54) de que:

A tradição de reformas educacionais tem se esmerado em atribuir ao currículo os problemas de qualidade da educação e, da mesma forma, seria ele o responsável pela superação das mazelas e desigualdades educacionais. Por isso, é importante não perdermos de vista a causa das desigualdades e o papel que a educação pode desempenhar na sua redução. Pensar o papel do currículo na correção das desigualdades é uma tentativa ingênua de deslocar processos de escolarização do contexto de uma sociedade profundamente desigual. 
O reconhecimento dos incontáveis aspectos negligenciados durante o processo de elaboração da BNCC, expresso também no excerto anterior, nos conduz à concordância em face da afirmação dos mesmos autores de que projeto em curso consistiu em "tornar um conjunto de conhecimentos, habilidades e competências, que não é, ainda, nem comum, nem nacional, comum e nacional através da obrigatoriedade de seu ensino" (CURY, REIS \& ZANARDI, 2018, p. 60). Por isso, faz-se tão relevante e necessário denunciar que "enquanto processo histórico há que se destacar que a BNCC não foi consensuada, não foi pactuada e, portanto, apresenta vários questionamentos acerca de sua legitimidade" (DOURADO \& SIQUEIRA, 2019, p. 294). Se é verdade, por um lado, que a formulação da Base não considerou a contribuição dos especialistas em educação, do campo do currículo, com ênfase às associações mencionadas, ou dos professores da Educação Básica, também é verdade que foram igualmente desconsideradas quaisquer perspectivas críticas sobre as juventudes brasileiras.

Recordar que inúmeros procedimentos adotados durante a formulação da Base a tornam, como política pública, frágil, inconsistente e ilegítima, nos inclina a questionar as reais intencionalidades mobilizadas pelos agentes relacionados à sua construção. Não é excesso recordar, aqui, que não foram tomados como interlocutores, na construção da política, as crianças, os jovens, os professores ou os pesquisadores da educação, mas, ao invés deles, representantes dos setores comerciais, mercadológicos e empresariais da educação. Nessa direção, tratar de sua participação, influência e mediação no decorrer do processo pode nos auxiliar a compreender também os motivos pelos quais foram negligenciadas as juventudes e as desigualdades sociais em que se inserem no país. Com Hypolito (2019, p. 194), que estudou a BNCC como decorrência de políticas econômicas globais, compreendemos, primeiro, que:

O modelo é o gerencialismo pretendido pelo GERM e pelas políticas neoliberais. Este modelo, que implica em parcerias público-privadas, com a terceirização da produção de materiais didáticos e venda de sistemas apostilados, com a inclusão de sistemas de gestão educacional, na forma de aplicativos ou plataformas digitais, que monitoram todo o sistema administrativo e pedagógico, retira das escolas e do professorado o controle sobre o que deve ser ensinado e como deve ser ensinado.

O reconhecimento de que, no percurso de formulação da política curricular, seria marcado pelo assédio dos reformadores empresariais - como tem chamado Freitas (2012) também foi considerado pelas associações educacionais desde o primeiro momento e se encontra registrada em uma das notas oficiais sobre as quais no dedicamos. Em nota, lemos que "a parceria estabelecida entre o MEC e fundações privadas, para a formulação e legitimação da BNCC, precisa ser discutida, principalmente em se tratando da contratação dessas empresas para a produção de material didático e implantação da base, antes mesmo de sua aprovação" (ABdC, 2017, pp. 2-3). 
Valemo-nos, por isso, das contribuições de Arelaro, Peroni \& Caetano (2019), que identificaram os principais agentes e grupos relacionados ao advocacy da Base no decorrer de seu processo de formulação. De acordo com o estudo realizado por elas,

O Movimento pela Base Nacional Comum (MBNC) que coordenou esse processo, num primeiro momento sem a presença do MEC, apresentou-se como um grupo não governamental de profissionais e pesquisadores da educação que atuava, desde 2013, para facilitar a construção de uma base de qualidade. Esse movimento foi patrocinado pela Fundação Lemann em conjunto com outras instituições públicas e privadas com o objetivo de direcionar a política educacional brasileira a partir de um projeto hegemônico para a educação. Em 2013, uma delegação brasileira participou, em caráter de Missão Oficial a convite da Fundação Lemann, do Seminário Internacional "Liderando Reformas Educacionais: Fortalecendo o Brasil para o Século XXI", realizado na Universidade de Yale, em abril de 2013, nos Estados Unidos, segundo Requerimento 227/2013/CE (Câmara de Educação). (ARELARO; PERONI; CAETANO, 2019, pp. 43-44)

O início do movimento já contava, portanto, com a participação e a influência de agentes privados e de seus interesses, também privados - o que se intensifica com seu desenrolar. Convergindo com o estudo feito por Hypolito (2019), as autoras identificam dentre os principais interlocutores relacionados ao processo grupos de agentes privados e públicos. Dentre os agentes privados, destacam "instituições que produzem materiais didáticos como Fundação Santillana e Abrelivros, Itaú-Unibanco, Instituto Ayrton Senna, Insper, Fundação Roberto Marinho, Instituto Natura e o Movimento Todos pela Educação, entre outros" (ARELARO; PERONI; CAETANO, 2019, p. 44). Já dentre os agentes públicos, as autoras identificam as "secretarias ligadas a governos do PSDB como São Paulo, Salvador, Goiás, Paraná, a UNDIME, representante dos secretários municipais de educação do país e o CONSED, que representa os secretários estaduais de educação, além do INEP, do MEC e Conselho Nacional de Educação", o que as leva a concluir que essa articulação "constitui-se num grupo hegemônico, que representa uma classe, em relação a um projeto educacional para o país" (p. 45).

A consideração tecida pelas autoras recoloca a centralidade da discussão sobre as tentativas de privatizar a educação pública, como nos mostra o mapeamento realizado pela Campaña Latinoamericana por el Derecho a la Educación (CLADE, 2014) em que seus autores apresentam e discutem sobre a existência de marcos regulatórios, marcos legais, que facilitam, estimulam ou impulsionam distintas formas de privatização. No trabalho citado,

Nota-se que a maior incidência refere-se às modalidades de privatização exógena: o subsídio público e a transferência de recursos para o setor privado e a compra de bens e serviços. Esta percepção é corroborada com o teor das legislações nacionais em vigor, que, na maioria das vezes, prevêem diversos mecanismos de repasse de recursos públicos a estabelecimentos privados e, além disso, em alguns casos, definem os critérios regulatórios do estabelecimentos que são considerados 
escolas públicas, de modo que diversas formas de escolas administradas pela iniciativa privada são incluídas na distribuição dos recursos públicos. (CLADE, 2014, pp. 81-82, tradução nossa)

No que se refere propriamente ao contexto de formulação da Base brasileira, consideramos ainda mais relevante a perspectiva enunciada pela CLADE (2014, p. 85, tradução nossa) de que:

A incorporação de atores e lógicas privatizadas, com ou sem fins lucrativos, questiona o caráter público da educação, o que tem consequências não apenas sobre a equidade no acesso à educação, por meio da fragmentação, segmentação e segregação da oferta educação, mas também levanta um problema político fundamental, no que se refere às práticas, valores e conteúdos que a educação pública deve promover como um processo democrático, no qual e por meio do qual os direitos fundamentais são realizados.

Privilegiar a interlocução com agentes e grupos privados em detrimento das associações de educadores, especialmente vinculadas às escolas e universidades públicas, revela, sem deixar sombra de dúvida, que houve, de forma escamoteada, a incorporação de que trata o excerto anterior, isto é, a incorporação não somente dos atores mas também de suas lógicas privatistas. Por isso, permaneceram rejeitadas as perspectivas provenientes da pesquisa educacional, das professoras e dos professores da Educação Básica, assim como de toda sociedade civil, em especial das juventudes.

Diametralmente oposta à concepção e à defesa de que "a educação deve estar sujeita ao controle público, o que significa que as políticas educacionais devem ser desenvolvidas de forma transparente e ser fruto de um debate público aberto" (CLADE, 2014, p. 9, tradução nossa), a Base se apresenta como resultado de um processo antidemocrático, "com o alijamento crescente dos diferentes segmentos da comunidade educacional em relação à produção da terceira versão que ficou nas mãos de representantes do MEC empresariado" (ANPEd, 2017a, p. 17). De acordo com a nota encaminhada pela entidade, esse processoproduto "representa o auge da lógica da promoção da mercantilização da educação, isto é, a vitória das empresas de educação que produzem materiais didáticos e estão à frente de instituições privadas de educação, viabilizando a comoditização definitiva da educação"12.

Nesse contexto, faz-se necessário incluir também o "alargamento da influência política de setores ultraconservadores e do fundamentalismo religioso no governo Temer", de acordo com Cássio (2019, p. 22), que o considera como fator que "contribuiu para que o texto da $\mathrm{BNCC}$ tenha se tornado ainda mais frágil do ponto de vista do combate às discriminações e da defesa dos direitos humanos". Porém, o autor também nos chama a atenção para a necessidade de "evitar a simplificação de reduzir a presença do campo empresarial nos processos de elaboração e de implementação da BNCC a um interesse mercantil direto nas várias formas de privatização da educação pública". Ainda que seja temerária, enquanto forma de privatização da educação pública, a participação desses agentes e setores privados na formulação da Base, consideramos que há uma ameaça contida nesse processo que deve 
ser considerada acima das demais, inclusive como justificativa para fomentar resistências criativas e criadoras, de que trataremos adiante, contra essa política de centralização e de controle curricular. Essa preocupação está expressa no seguinte excerto:

Se há de fato empresas educacionais que vislumbram as oportunidades comerciais abertas com a implementação da Base nas redes públicas (venda de materiais didáticos, de pacotes de formação docente de baixo custo, de serviços diversos), o grande interesse dos institutos e fundações empresariais (...) nas reformas educacionais de alcance nacional é político-econômico: a disputa de projetos societários para o país a partir das agendas dos grupos econômicos que mantêm estas instituições. (CÁSSIO, 2019, p. 23, rodapé)

Se considerarmos os estudos de Hypolito (2019) articulados à argumentação acima, poderemos compreender a BNCC brasileira como uma resposta às demandas impostas pelos reformadores educacionais (Freitas, 2012), decorrentes, em especial, das políticas econômicas globais, nomeadamente expressas pelo Banco Mundial. Trata-se, não obstante, de uma disputa desleal em torno da política curricular, que a concede como mecanismo para garantir a influência permanente de certos grupos, que constituem uma hegemonia como demonstram Arelaro; Peroni; Caetano (2019), a despeito das contribuições e críticas elaboradas pela comunidade acadêmica e educacional brasileira - manifestas por meio das notas e dos ofícios das associações científicas.

Pautando-se em um estudo realizado pelas pesquisadoras Lois Weiner e Mary Compton, Hypolito (2019, p. 190), sintetiza as principais premissas identificadas pelas autoras no documento "Professores excelentes - como melhorar a aprendizagem dos estudantes na América Latina e no Caribe", do Banco Mundial:

Premissa 1: a pobreza na América Latina e Caribe pode ser mais efetivamente reduzida por intermédio da reforma educacional;

Premissa 2: a América Latina e o Caribe constituem um contexto político, econômico, social e educacional único em que a mesma política educacional pode ser aplicada com efeito igual e positivo;

Premissa 3: melhorar a qualidade docente, conforme capturada pelo desempenho dos estudantes em testes padronizados e medidas de valor agregado, é a forma mais eficaz de melhorar os resultados educacionais na América Latina e Caribe; Premissa 4: a baixa qualidade docente, medida pelo uso do tempo de ensino, demonstra que a composição do magistério deve ser mudada;

Premissa 5: o obstáculo primário para melhorar a educação pela elevação da qualidade docente é o poder político dos sindicatos de professores, os quais, por esse motivo, devem ser profundamente enfraquecidos.

Ainda que Hypolito apresente sua argumentação em desfavor das premissas mobilizadas pelo documento, remetemo-nos às investigações de Rosa Alonso (2018, p. 11-12, tradução nossa) para questioná-las, por entendê-las também relacionadas à formulação da BNCC: 
As pessoas não se enganam ... a região da América Latina e do Caribe continua a ser a mais desigual do planeta em termos de distribuição de renda, apesar do avanço dos últimos anos. A desigualdade é um importante indicador da qualidade de uma democracia, uma vez que toda democracia parte do reconhecimento de que todas as pessoas têm direitos iguais. Nesse sentido, é função dos Estados garantir progressivamente os direitos econômicos, sociais e culturais (DESC) a todas as pessoas de forma igualitária (...) Esses níveis de desigualdade mostram que a igualdade de direitos e deveres ainda está longe de ser cumprida. na região. Essa igualdade é o princípio fundamental da democracia e a impossibilidade de alcançá-la gera um círculo vicioso, o que torna imprescindível considerar a captura do Estado e de suas políticas públicas pelas elites como questão fundamental na luta pela desigualdade. Somente fortalecendo a democracia e limitando a captura do Estado pelas elites, a desigualdade pode ser reduzida. Somente reduzindo a desigualdade, garantindo que as políticas públicas não privilegiem uma elite, podemos ter mais democracia.

Compreender como se relacionam desigualdades sociais e democracia, como sugere Alonso no excerto anterior, nos auxilia a suspeitar e a tensionar os discursos salvacionistas ligados ao advocacy da Base, inclusive por ela própria não ter sido uma política gestada sob o rigor dos princípios democráticos. Posto isso, recorremos às pesquisas da mesma autora sobre a temática do sequestro da democracia para compreender a Base - e seu processo de formulação - como um movimento fragmentado, conservador, autoritário e contraditório que mobiliza, no campo da política educacional, ferramentas relacionadas à implosão da democracia brasileira. Para isso, consideramos necessário compreender que:

O sequestro da democracia se expressa de várias maneiras. Influência na definição de políticas, adotando a forma de lobby ilegítimo e tráfico de influências; corrupção, que se concreta, por exemplo, no estabelecimento irregular e não transparentes de contratos, superfaturamento de obras ou venda de terrenos estatais subavaliados; o clientelismo, que se manifesta em compra de votos, contratação de funcionários públicos somente por indicação política, priorização de políticas assistenciais e concessão de serviços públicos como favores. Algumas são ilegais... Outras são legais, mas todas elas são ilegítimas. (ALONSO, 2005, p. 9)

Dar a devida gravidade aos procedimentos ilegítimos de formulação e homologação da Base brasileira corresponde a compreendê-la, no contexto do sequestro da democracia brasileira - o mesmo que se inicia com o golpe da presidenta Dilma Rousseff - como uma ferramenta que garante a influência de certos - e poucos - grupos privados na definição de políticas públicas, leis e marcos regulatórios. Nesse processo, como Alonso (2005, p. 11) nos conta, "as elites incidem na orientação e natureza das políticas públicas e da legislação; e determinam prioridades sociais e econômicas para seu próprio benefício econômico ou partidário em detrimento da sociedade em seu conjunto", o que, sem dúvida, marca o processo de formulação da BNCC. 
Trata-se, como afirma a autora, de compreender a captura da democracia, para e por um governo de poucos, como "o exercício de influência abusiva por parte de uma elite - a favor dos seus interesses e prioridades e em detrimento do interesse geral - ao longo do ciclo das políticas públicas e dos órgãos do Estado, com efeitos potenciais sobre a desigualdade e o bom desempenho da democracia" (ALONSO, 2018, p. 14, tradução nossa). A celeridade do processo de formulação da Base brasileira e sua rápida conclusão descarta como hipótese a possibilidade de que seus formuladores sejam considerados meramente incompetentes, porque não hesitaram em desconsiderar toda e qualquer contribuição crítica e legítima tanto de setores progressistas da sociedade civil, como as juventudes, como professoras e professores da Educação Básica, além das associações educacionais de que tratamos no decorrer deste texto.

Tanto os formuladores da política como os reformadores empresariais que se vincularam ao MEC durante o processo, além evidentemente dos membros do CNE responsáveis pela aprovação da BNCC, se apresentaram desde o início com muita convicção sobre a ideia de que a Base responderia às desigualdades sociais e às diferenças, ainda que não houvesse qualquer consideração adequada da complexidade como se articulam no cenário brasileiro. Descartada a hipótese de que não sabiam o que estavam fazendo, dado seu compromisso com a efetivação da política curricular centralizadora, a despeito de todas as críticas feitas pelas associações em diversos momentos do processo, resta-nos compreender tal movimento como ferramenta necessária, ainda que não suficiente, para mobilizar o sequestro da democracia brasileira, cuja captura se inicia com o golpe jurídico-midiático aplicado sobre Dilma.

Concordamos por isso com a seguinte perspectiva:

A formulação e implementação de políticas não acontecem no vácuo. Normalmente, ocorre em espaços onde existem assimetrias de poder. Quando o ciclo das políticas públicas ocorre em contextos caracterizados por profundas desigualdades, geralmente são as elites, aqueles atores que concentram o poder de influência sobre o processo político, que permeiam as políticas resultantes com seus interesses. Assim, a cultura de privilégios prevalecente em nossa região é reforçada. Em outras palavras, assimetrias de poder de influência estão por trás da desigualdade socioeconômica, e vice-versa, uma vez que existem atores que usam esse poder para "capturar" certas políticas e, eventualmente, capturar o Estado. Portanto, o valor técnico ou "justeza" de uma apólice não é garantia de que ela será executada com sucesso. Pelo contrário, as características do contexto político são um fator chave. Os níveis de desigualdade e de insatisfação dos cidadãos com o funcionamento da democracia falam-nos de mecanismos nos quais algumas elites cooptam, corrompem ou distorcem a natureza das instituições democráticas para promover políticas que mantenham a posição privilegiada dessas elites. (...) Esse processo deu origem a sistemas democráticos em que, por vezes, poucos elaboram políticas públicas em benefício próprio, o que contribui para o círculo vicioso da reprodução das desigualdades e dá origem a desequilíbrios no exercício dos direitos. direitos e representação política. (ALONSO, 2018, p. 13, tradução nossa) 
O que Alonso nos informa, para refletir sobre a Base Nacional Comum Curricular brasileira, é a necessidade de recusá-la, dado seu caráter autoritário e centralizador, característico das mencionadas ocasiões em que uns poucos - realmente muito poucos, dada a complexidade do sistema educacional brasileiro - desenham as políticas para seu próprio benefício.

O fato de que, a despeito de seus inúmeros vícios - pecados de origem - discutidos na primeira metade deste trabalho, a Base foi aprovada e homologada demonstra que as instituições, em especial $\mathrm{MEC}$ e $\mathrm{CNE}$, não cumpriram com o rigor democrático que foi alardeado os procedimentos no decorrer de sua formulação. Qualquer fato isolado - desde as pouquíssimas contribuições obtidas na consulta pública (as "doze milhões") e seu posterior abandono, até o modo como a pedagogia das competências é introduzida como fundamentação pedagógica exclusiva, organizando todas as etapas da Educação Básica, passando pela inobservância da necessidade de incluir o Ensino Médio junto às demais etapas - poderia ter sido tomado como justificativa mais do que suficiente para sua rejeição no momento da votação. A desconsideração pelas associações educacionais, pelo papel das universidades e escolas públicas na construção da política, denotada pela flagrante e vexatória falta de respostas minimamente respeitosas e adequadas aos ofícios e notas encaminhados, também poderia ter sido suficiente para sua recusa.

Porém, a Base foi aprovada em detrimento de apenas três votos contrários.

A política curricular nacional, objetivada pelos agentes de seu advocacy, na formulação da BNCC, tornou obrigatórios não somente um conjunto de competências e habilidades arbitrárias, convencionais apenas para seus formuladores, mas, principalmente, concepções de educação, de ser humano e de escola profundamente ideológicas, questionáveis e inconsistentes.

A Base, cujo processo de formulação desprezou sem hesitar quaisquer contribuições dissonantes ao modelo que já era esperado como produto, reflete interesses hegemônicos, inclusive como resposta às demandas da política econômica global, que se impõem na disputa de projetos societários para o país, como já lemos, a partir da agenda de grupos que foram privilegiados como interlocutores dessa formulação. Essa preocupação esteve também refletida nos documentos produzidos pelas associações educacionais, como no excerto a seguir:

Estamos convictos que a BNCC (...) vai impactar negativamente a formação de professores ao impor uma lógica centralizadora nos processos educativos e a vinculação intrínseca a avaliações de larga escala de instituições, professores e estudantes, para a geração de índices de desempenho que em nada asseguram a melhoria do ensino ou a qualidade dos processos formativos. (...) Nesse sentido, rejeitamos a implementação de uma Base Nacional Comum Curricular dissociada das demandas formativas e realidades locais, que não foi alvo de discussão nas escolas, em cada município e estado brasileiro, e nem será, pois já está aprovada e sendo imposta a sua adoção. Agora a BNCC está sendo utilizada como referencial para programas de formação inicial de professores, como os 
apresentados pelos editais CAPES $\mathrm{N}^{\circ}$ 06/2018 e $\mathrm{N}^{\circ}$ 07/2018, que tratam, respectivamente, sobre o Programa de Residência Pedagógica (PRP) e do Programa Institucional de Bolsa de Iniciação à Docência (Pibid), sobre os quais manifestamos posicionamento de crítica e resistência junto outras entidades cientificas, em março de 2018. (...) A complexidade de uma política curricular nacional é incompatível com a adoção de matrizes curriculares homogeneizadas, que ameaçam o princípio federativo republicano da autonomia dos sistemas estaduais e municipais de ensino e a construção dos projetos político-pedagógicos das instituições escolares, como explicitado nas Diretrizes Curriculares Nacionais da Educação Básica (Res. CNE/CB n.4, de 13/7/2010). (ANFOPE, 2018, pp. 2-3)

Aceitá-la, portanto, nos faz aprofundar ainda mais o processo de captura de nossa jovem democracia, de seu sequestro, dada sua influência sobre a escolha de livros e materiais didáticos, seus impactos sobre a formação de professores e, especialmente, a tentativa de controle dos currículos escolares praticados por meio das avaliações em larga escala, para as quais a Base já teria, inclusive, incorporado códigos como descritores das habilidades e competências que se espera "desenvolver" nas crianças e nos jovens brasileiros.

\section{Conclusão - Por outras bases para a política pública educacional brasileira}

\section{"É nosso dever moral e obrigação desobedecer a uma lei injusta" \\ Martin Luther King}

Valemo-nos da epígrafe acima não somente para nos recordar de nosso dever moral de recusar a uma lei injusta, especialmente num contexto democrático, quando são desrespeitados e desconsiderados os saberes dos praticantes legítimos do currículo ${ }^{13}$, educadores, jovens e suas famílias, assim como toda contribuição crítica das associações de educadores. Nesse sentido, introduzimo-nos às conclusões construídas por meio desta investigação com a consideração de que:

A BNCC em nada se assemelha a base comum nacional gestada, coletivamente, em meio a luta democrática de profissionais da educação pela participação nas discussões acerca das propostas de formação de professores no contexto de redemocratização no Brasil, na década de 1980. A base comum nacional, que defendemos historicamente e que está contemplada nas Diretrizes Curriculares Nacionais para a Formação para a Formação Inicial e Continuada de Professores (Resolução CNE $N^{\circ}$ 02/2015), é uma concepção básica de formação do educador e um corpo de conhecimento fundamental em que a docência se constitui como a base da identidade profissional de todo educador, e, portanto, não pode ser confundida como um currículo mínimo ou um elenco de disciplinas. (ANFOPE, 2018, p. 2) 
Junto à perspectiva manifesta pela entidade, acrescentamos a perspectiva da pesquisadora Inês Barbosa de Oliveira (Universidade Estadual do Rio de Janeiro/UERJ) que, no decorrer do processo de formulação da Base brasileira, atuou como presidenta da Associação Brasileira de Currículo, ABdC, de cujos ofícios e notas tratamos neste trabalho. Para ela, "a BNCC pressupõe, equivocadamente, que a melhoria da qualidade das aprendizagens seria produzida por meio de um currículo único para estudantes de todo o país, controlado de fora da escola por avaliações de larga escala e material didático padronizado" (Oliveira, 2018, p. 56). A autora nos recorda de que a Base surge enredada também pela Meta 7, cujos perigos já haviam sido previstos anteriormente pelas entidades. Em suas palavras, "entre outros problemas e equívocos, a meta 7 do PNE reduz a compreensão da melhoria do ensino à melhoria do IDEB das escolas, quantificando resultados a partir de graus em provas e índices de permanência e aprovação escolar" (p. 56).

Assim, a pesquisadora critica, sem desconsiderar a relevância desses indicadores para auferimento da qualidade do ensino, a possibilidade de tomá-los em exclusividade para mensurar a qualidade da educação, o que implica a "desconsideração das condições e circunstâncias distintas que enfrentam professores e alunos nas escolas brasileiras; da pluralidade social, cultural e econômica do país, bem como de outros fatores inapreensíveis por meio de exames e índices" (OLIVEIRA, 2018, p. 57). Aprofundando-nos no sentido de sua crítica, lemos ainda que:

No caso da BNCC, é a estratégia 7.1 que a enuncia como necessária, e explicita que ela deve ser baseada em objetivos de aprendizagem. A estratégia 7.36 propõe políticas de "estímulo" às escolas que melhorarem o Ideb. Fala em valorizar o mérito do corpo docente, da direção e da comunidade escolar, desconsiderando, mais uma vez, as especificidades das realidades em que atuam, além de incentivar mais a busca de resultados em exames do que a qualidade do processo ensinoaprendizagem. Ou seja, é uma estratégia que, ao valorizar financeiramente o docente cujos alunos obtêm sucesso nas avaliações de larga escala, o desqualifica pelo controle externo sobre seu fazer. Efeito inevitável da combinação dessas estratégias para o atingimento da meta em questão, a perspectiva meritocrática assumida tende a ampliar as desigualdades e a reforçar processos de exclusão social. Nesse sentido, o exame dos processos de discussão que deram origem a BNCC (estratégia 7.1 da meta 7) e dos argumentos elencados pelo governo em sua defesa permite perceber uma intencionalidade privatista e mercantil e um discurso de homogeneização que, como afirmamos acima, reforça e reproduz processos históricos de produção da exclusão social e confirma a profunda e intensa desvalorização da função docente por este governo. (OLIVEIRA, 2018, p. 57)

Nessa direção, resgatar e tornar públicas as condições em que foram formuladas as versões da BNCC, denunciar seus equívocos político-epistemológicos, inclusive em fóruns internacionais de debate público sobre a educação na América Latina e no Brasil, faz-se necessário a fim de que possamos ensejar, de distintas formas, as resistências necessárias 
contra tamanha injustiça deflagrada. Por isso, resgatamos, no decorrer deste trabalho, desde os argumentos mobilizados pelos agentes responsáveis pelo advocacy da Base até a história de seu processo de formulação, para evidenciar seu caráter antidemocrático, tanto quanto desonesto intelectualmente com o povo brasileiro, mais uma vez furtado de seu direito de participar e de decidir.

Posto isso, manifestamo-nos, em concordância com as associações educacionais brasileiras que, em nota elaborada sobre os motivos que as faziam questionar a BNCC para o Ensino Médio, endereçam-nos pautas efetivamente comprometidas com a qualidade social da educação pública:

Para surpreender, fechamos este documento declarando que somos favoráveis e trabalhamos, como a ampla maioria dos pesquisadores e professores, por uma base para a educação básica do país. A base é uma Universidade pública e democrática, que atue com responsabilidade social e forme professores inicial e continuadamente num ambiente de pesquisa e cultura e troca permanente com as redes municipais e estaduais. A base é, também, a dedicação exclusiva do professor a uma escola, com salário que permita a esse professor uma vida digna. A base é um conjunto de estudantes que podem comer e recebem ação do Estado no sentido do atendimento de suas necessidades básicas de saúde, habitação e saneamento, cultura e lazer, transporte. A base é ter escolas com boas condições materiais e de infraestrutura. E para surpreender, ainda mais, sabe de onde emergem essas ideias? Dos resultados das políticas implementadas pelas demandas por accountability que têm, reiteradamente, mostrado que as melhores escolas são aquelas em que essas bases são garantidas. Isso é base, e o que tem sido chamado de base é a pretensão de definir o horizonte logo ali onde os olhos do controle podem alcançar. (ANPEd; ABdC, 2018, p. 20) ${ }^{14}$

Argumentamos, portanto, que temos como alternativa - e, talvez, como caminho para a resistência criativa, criadora e democrática à Base - compreender que o direito à educação, muito mais do que direito à aprendizagem, se estenda à participação efetiva dos atores pertencentes às comunidades escolares, por mais distintas que sejam em todo o país, nas negociações e decisões sobre a política curricular. Afinal, como seus efetivos produtores esses sujeitos não podem ser furtados ou impedidos em seu direito à educação, amplo como sugere Rosa Maria Torres (2006) ${ }^{15}$.

Esse reconhecimento do direito à educação e das necessidades que dele decorrem pode orientar outras bases, fundamentais à política educacional brasileira como têm argumentado diferentes pesquisadoras e pesquisadores das universidades públicas e que compõem as associações de educadores que, no decorrer de todo o processo de formulação da Base, foram ignorados e negligenciados. Muito do conteúdo dessas outras bases já está presente no excerto anterior, porém, como conclusão deste trabalho, gostaríamos de propor o acréscimo de outra base, indispensável a qualquer melhoria real da escola pública brasileira: a radicalização do sentido público da escola pública, que não se faz fora de um contexto democrático. 
Recusar e resistir à Base Nacional Comum Curricular é o dever moral, parafraseando Martin Luther King, de educadoras e de educadores comprometidos com a democracia, inclusive pelo reconhecimento de que não há esperança que germine e floresça fora do terreno fértil da democracia, que rejeita o utilitarismo vazio dos interesses privados (HOUTART, 2009). Fora da democracia, só há incerteza e medo (SANTOS, 2016).

A esperança no sentido público da escola pública reflete a certeza de que "não é necessário que todas as escolas tenham o mesmo currículo: o currículo precisa fazer sentido e ser construído contextualmente, atender demandas e necessidades que não são homogêneas" (LOPES, 2018, p. 25). Isso nos permite concluir com um fato ignorado pelo MEC e pelo CNE, inclusive pelo desprezo com que trataram as notas e os ofícios das entidades educacionais, onde poderiam ter aprendido que "sujeitos diferentes não produzem nem mobilizam os mesmos saberes, não se inserem nas mesmas experiências de vida, não constroem os mesmos projetos de futuro. Além de não ser necessário que o currículo seja igual em todo país, também não é possível que o currículo seja igual" (LOPES, 2018, p. 26).

Remetemo-nos, enfim, ao mestre e maior educador brasileiro Paulo Freire, a fim de dizer em coro com ele, as últimas palavras deste trabalho.

Mas, se para a concepção "bancária" a consciência em sua relação com o mundo, esta "peça" passivamente escancarada a ele, à espera de que entre nela, coerentemente concluirá que ao educador não cabe nenhum papel que não o de disciplinar a entrada do mundo nos educandos. Seu trabalho será, também, o de imitar o mundo. $\mathrm{O}$ de ordenar o que já se faz espontaneamente. O de "encher" os educandos de conteúdos. É o de fazer depósitos de "comunicados" - falso saber - que ele considera como verdadeiro saber. (...) Quanto mais se adaptam as grandes maiorias às finalidades que lhes sejam prescritas pelas minorias dominadoras, de tal modo que careçam aquelas do direito de ter finalidades próprias, mais poderão estas minorias prescrever. (FREIRE, 2014, p. 88)

Reconhecer, assumir e radicalizar o sentido público da escola pública passa, portanto, por compreender que diferentes comunidades escolares experimentam a realidade de distintas formas, concebendo suas próprias finalidades também de diversos modos. Cabe às escolas buscar caminhos para interagir com tais finalidades, voltando-se à escuta e ao estímulo da participação em seu contexto local, construindo objetivamente seus currículos a partir do que trazem seus interlocutores diretos, tanto em termos de possibilidades como em termos de limitações, de suas situações-limite, para citarmos Freire (2014) novamente.

Esse movimento, dedicado e desperto, criativo e criador, ajuda com que percebamos, mais e mais, que temos nossas próprias finalidades, tão diversas e distintas quanto nós mesmos brasileiros, e não faz o menor sentido que tenhamos de assumir essas finalidades outras, de que fala Freire, que não são nossas, mas de um pequeno grupo, de um governo de poucos, que tenta impor sobre nós suas vontades e seus interesses. Não deixemos que sequestrem nossa jovem democracia! É preciso cuidar dela, em cada detalhe, e isso passa por recusarmos a Base brasileira, por compreendê-la como produto de um processo que manifestou por ela tanto desprezo e tanto descuido. 


\section{Notas}

1. É relevante, ainda, elucidar que os valores do IDEB se constituem a partir dos dados de fluxo escolar (aprovação/reprovação/abandono) associados aos dados de proficiência/desempenho obtidas em avaliações padronizadas de língua portuguesa e matemática, aplicadas em todo o território nacional. Não há consenso no campo educacional sobre a fundamentação do indicador, mas há, ao invés disso, muitas críticas relacionadas ao fato de que a qualidade da educação escolar brasileira tem sido considerada apenas sob a perspectiva dessa mensuração. Algumas dessas críticas podem ser consultadas na página coordenada pelo professor e pesquisador Luiz Carlos de Freitas: https://avaliacaoeducacional.com/category/exames-e-indices/ideb/

2. Além das já mencionadas anteriormente, as demais entidades são: ANFOPE - Associação Nacional pela Formação dos Profissionais da Educação; CEDES - Centro de Estudos Educação e Sociedade FORUMDIR - Fórum Nacional de Diretores de Faculdades, Centros de Educação e Equivalentes das Universidades Públicas Brasileiras

3. É importante sublinhar aqui o fato de que a ideia de uma base nacional comum ainda não estava acompanhada de sua adjetivação "curricular", que seria adotada posteriormente, como nos contam as autoras Arelaro, Peroni e Caetano (2019, p. 42): "Houve uma inflexão dos conceitos presentes entre a primeira versão e a que foi aprovada pelo CNE em 2017; exemplo disso, é o conceito de base nacional comum e base nacional curricular comum, direitos de aprendizagem e competências e habilidades, ou seja, a própria concepção curricular que norteia a base".

4. Essa percepção se reforça pela constatação de que, no período que antecedeu a formulação da Base, "o debate público sobre o currículo da Educação Básica é travado nos cadernos 'Mercado' dos grandes jornais. Todos eles produziram matérias favoráveis sobre a Base, bem como a mídia especializada em economia: o jornal Valor Econômico e as revistas Exame, IstoÉ Dinheiro e Época Negócios”. (Cássio, 2019, p.15)

5. Cássio (2019, p. 28) ainda afirma que: "quanto às contribuições efetivas depositadas na consulta, as sugestões de inclusão e de modificação que perfazem $1,52 \%$ do total de 'contribuições', não há nenhuma indicação nos relatórios públicos do MEC de como elas foram analisadas ou incorporadas à segunda versão da BNCC".

6. Fonte: http://basenacionalcomum.mec.gov.br/historico

7. A adesão de escolas em distintas localidades do país encontra-se registrada, junto à divulgação das práticas invisibilizadas mais uma vez pela política de endurecer o currículo, na plataforma: http://www.anped.org.br/campanha/curriculo

8. Cássio (2019) trata de "reincorporação" devido ao fato de que a pedagogia das competências já havia estruturado, nos anos 1990, os Parâmetros Curriculares Nacionais (PCN).

9. Sob a perspectiva de Dourado \& Siqueira (2019, p. 297), "a pedagogia das competências reafirma o modelo de gestão empresarial de responsabilização individual dos sujeitos frente aos processos de aprendizagem e apropriação do conhecimento". Conforme afirmam os autores, esse movimento se confirma por meio tanto da centralização curricular como também da adoção de um modelo de aprendizagem cognitivista. Posto isso, os autores ainda elucidam que: "o conhecimento prático requerido nas habilidades e competências da BNCC é aquele marcado pela lógica pragmática, utilitarista e reducionista. É preciso considerar "aquilo que os estudantes devem aprender na Educação Básica, o que inclui tanto os saberes quanto a capacidade de mobilizá-los e aplicá-los." (BRASIL, 2017, p.12). Um conhecimento que traga aos estudantes "o estímulo à sua aplicação na vida real." (Idem, p. 15) Essa concepção gerencial e pragmática, se materializada, poderá resultar em matrizes e dinâmicas curriculares mais operacionais e padronizadas, pautadas por uma secundarização das Ciências Humanas e Sociais e das Artes em geral” (Dourado \& Siqueira, 2019, p. 298).

10. Consideramos relevante, aqui, nos remetermos à observação feita por Arelaro, Peroni \& Caetano (2019, p. 46) de que "essa é a primeira vez que o MEC apresenta uma proposta oficial, afirmando que ela será obrigatória, contrariando dispositivo constitucional que garante o 'pluralismo de ideias e de concepções pedagógicas', como direito do ensino brasileiro (art. 206, III, Constituição Federal, BRASIL,1988)”.

11. Concordamos enfaticamente com a perspectiva de Macedo (2018, p. 31), que afirma que "estamos jogando fora uma experiência de formação de professores e de pesquisa das Universidades brasileiras para 'comprar' parcerias internacionais contestadas em seus cenários nacionais e que pouco conhecem da nossa tradição".

12. Em nota, outra associação educacional, a Associação Nacional pela Formação dos Profissionais da Educação (ANFOPE, 2018, p. 2), declara: "Consideramos que esse processo foi conduzido de forma verticalizada, simulando um diálogo parcial com a sociedade, adotando uma metodologia que priorizou contribuições quantitativas em detrimento de 
proposições qualitativas, não sendo, portanto, promotor de 'ampla consulta pública nacional', como alardeado. A imposição da terceira versão, que desconsiderou as críticas propositivas das entidades educacionais - apresentadas antes e durante as cinco audiências realizadas, - e privilegiou as posições defendidas por setores do empresariado interessados na padronização do ensino, apenas confirmou que não havia interesse em estabelecer o necessário diálogo que a discussão de uma base curricular nacional exigiria".

13. Valemo-nos, aqui, da crítica formulada por Oliveira \& Süssekind (2018, p. 59) de que a Base brasileira "ignora a existência de conhecimentos anteriores e externos à escolarização, fundantes dos modos de compreender o mundo e de agir sobre ele desses mesmos estudantes. Assim, ao desrespeitar esses saberes anteriores com os quais os estudantes chegam às escolas, assume como ignorância a bagagem histórica, social e cognitiva destes, e, ao fazê-lo, a invisibiliza e torna inexistente, transformando sujeitos de conhecimentos em sujeitos de ignorância, e contribuindo, com isso, para a hegemonia do pensamento conteudista cientificista sobre outras compreensões de educação, mais plurais epistemologicamente, mais dialógicas e, portanto, mais democráticas".

14. Vale acrescentar, aqui, a perspectiva convergente de Cássio $(2019$, p. 19) de que "seria possível pensar nas diversas formas de impactar positivamente os indicadores educacionais: melhorar a infraestrutura das escolas, melhorar as condições do trabalho docente, aumentar os salários dos profissionais da educação, investir em formação docente qualificada, ampliar o alcance das políticas sociais, etc. As metas e estratégias do Plano Nacional de Educação 20142024 (PNE) trazem isso e muito mais. Ocorre que, passados quatro anos da aprovação da Lei n. 13.005/2014, muito pouco do PNE foi efetivamente cumprido. Algumas de suas diretrizes e metas têm sido, aliás, deliberadamente descumpridas, como as diversas estratégias relacionadas à Meta 20, que trata da ampliação do investimento público em educação pública".

15. Sob a perspectiva de Torres (2006, p. 24, tradução nossa), "não é suficiente ter acesso à escola, educação e aprendizagem ao longo da vida. O direito à educação implica o direito de participar, em cada esfera e nível, das decisões e relações que regem a vida escolar e outros ambientes educacionais. Estudantes, educadores, pais e cidadãos em geral têm o direito de ser consultados em todos os aspectos da educação - metas e objetivos, conteúdos e métodos, organização e gestão, orçamento e fontes de financiamento, cooperação internacional - bem como exigir informação e responsabilização dos responsáveis em cada caso".

\section{Referências}

ABDC, Associação Brasileira de Currículo. Documento produzido pela Associação Brasileira de Currículo (ABdC) encaminhado ao CNE no contexto das Audiências públicas sobre a BNCC. 2017. Disponível em: http:/www.anped.org.br/sites/default/files/images/documento_abdc_bncc_2017.pdf. Último acesso em: 07 setembro 2020.

Nota sobre processos de implantação da Base Nacional Comum Curricular do Ensino Fundamental. 2018. Disponível em: https://fce3adf-21b8-44d9-9b12-da4e0971a909.filesusr.com/ ugd/f7609a_48c14647478d4109ab23fbf7889d94d2.pdf. Último acesso em: 07 setembro 2020.

AGUIAR, M. A. Relato da resistência à instituição da BNCC pelo Conselho Nacional de Educação mediante pedido de vista e declarações de votos. In: DOURADO, L. F.; AGUIAR, M. A. (Orgs.). A BNCC na contramão do PNE 2014-2024: avaliação e perspectivas. Recife: ANPAE, 2018, pp. 8-22.

ALONSO, R. C. Privilégios que negam direitos: desigualdade extrema e sequestro da democracia na América Latina e o Caribe. Santo Domingo: Editora Búho/OXFAM INTERMON, 2005.

Democracias capturadas: el gobierno de unos pocos. Buenos Aires: CLACSO/Oxfam, 2018.

ANFOPE, Associação Nacional pela Formação dos Profissionais da Educação. Nota de Comissão Bicameral do Conselho Nacional de Educação sobre a Formação Inicial e Continuada de Professores. 2018. Disponível em: http://www.anfope.org.br/wp-content/uploads/2018/05/ANFOPE-CNE-9abr-2018-.pdf Último acesso em: 07 Setembro 2020.

ANPEd, Associação Nacional de Pós-graduação e Pesquisa em Educação. Ofício n. 138/2015 - A Associação Nacional de Pós-Graduação e Pesquisa em Educação e a Base Nacional Comum Curricular. 2015. 
Disponível em: http://www.anped.org.br/sites/default/files/images/a_anped_e_a_bncc_versao_final.pdf Último acesso em: 07 Setembro 2020.

Ofício n. 31/2016 - Aos deputados da Comissão de Educação da Câmara de Deputados. 2016. Disponível em: http://www.anped.org.br/sites/default/files/images/oficio_anped_031_2016_aos_ deputados_da_comissao_de_educacao_da_camara_de_deputados.pdf Último acesso em: $0 \overline{7}$ Setembro 2020.

Nota sobre a entrega da terceira versão da Base Nacional Comum. 2017a. Disponível em: http://www.anped.org.br/news/nota-da-anped-sobre-entrega-da-terceira-versao-da-base-nacional-comumcurricular-bncc-ao_Último acesso em: 07 Setembro 2020.

Ofício de "Solicitação de respostas às notas das entidades educacionais". 2017b. Disponível em: http://www.anped.org.br/sites/default/files/images/oficio_cne_04.12.17.pdf Último acesso em: 07 Setembro 2020.

A proposta de BNCC do ensino médio: alguns pontos para o debate. 2018. Disponível em: http://www.anped.org.br/news/nota-anped-proposta-de-bncc-do-ensino-medio-alguns-pontos-para-odebate Último acesso em: 07 Setembro 2020.

ANPEd, Associação Nacional de Pós-graduação de Pesquisa em Educação. ABDC, Associação Brasileira de Currículo. Ofício n⿳0 01/2015 - GR: Exposição de motivos sobre a Base Nacional Comum Curricular. 2015. Disponível em: http://www.anped.org.br/sites/default/files/resources/Of_cio_01_2015_CNE_BNCC.pdf Último acesso em: 07 Setembro 2020.

Exposição de motivos BNCC-EM. Disponível em: http://www.anped.org.br/sites/default/files/ images/anped_abdc_contrabncc-emago2018final.pdf Último acesso em: 07 Setembro 2020.

ARELARO, L. R. G.; PERONI, V. M.; CAETANO, M. R. BNCC: disputa pela qualidade ou submissão da educação? RBPAE, v. 35, n. 1, 2019, pp. 35-56.

BRASIL. Constituição da República Federativa do Brasil. Brasília/DF: Senado Federal/Centro Gráfico, 1988.

Lei de Diretrizes e Bases da Educação - Lei Federal no 9.394 de 1996. Disponível em: http://www.planalto.gov.br/ccivil_03/leis/19394.htm Último acesso em: 07 Setembro 2020.

Base Nacional Comum Curricular. 2017. Disponível em: http://basenacionalcomum.mec.gov.br Último acesso em: 07 Setembro 2020.

CLADE, Campaña Latinoamericana por el Derecho a la Educación. Mapeo sobre tendencias de la privatizacion de la educación en América Latina y el Caribe. São Paulo: CLADE, 2014.

CÁSSIO, F. Existe vida fora da BNCC? In: CATELLI Jr., R.; CÁSSIO, F. (Orgs.). Educação é a Base? 23 educadores discutem a BNCC. São Paulo: Ação Educativa, 2019.

CURY, C. R. J.; REIS, M.; ZANARDI, T. A. Base Nacional Comum Curricular: dilemas e perspectivas. São Paulo: Cortez, 2018.

DOURADO, L. F.; AGUIAR, M. A. (Orgs.). A BNCC na contramão do PNE 2014-2024: avaliação e perspectivas. Recife: ANPAE, 2018.

DOURADO, L. F. \& SIQUEIRA, R. M. A arte do disfarce: BNCC como gestão e regulação do currículo. RBPAE, v. 35, n. 2, 2019, pp. 291-306.

FREIRE, P. Pedagogia do Oprimido. Rio de Janeiro: Paz e Terra, 2014, $57^{\mathrm{a}}$ ed.

FREITAS, L. C. Os reformadores empresariais da educação: da desmoralização do magistério à destruição do sistema público de educação. Revista Educação \& Sociedade, v. 33, n. 119, 2012, pp. 379-404.

HOUTART, F. Deslegitimar o capitalismo, reconstruir la esperanza. Buenos Aires: CLACSO, 2009.

HYPOLITO, A. M. BNCC, Agenda Global e Formação Docente. Revista Retratos da Escola, Brasília, v. 13, n. 25,2019 , pp. 187-201. 
LOPES, A. C. Por um currículo sem fundamentos. Linhas Críticas, v. 21, n. 45, 2015, pp. 445-466.

Apostando na produção contextual do currículo. In: DOURADO, L. F.; AGUIAR, M. A. (Orgs.). A BNCC na contramão do PNE 2014-2024: avaliação e perspectivas. Recife: ANPAE, 2018, pp. 23-27.

MACEDO, E. "A base é a base”. E o currículo, o que é? In: DOURADO, L. F.; AGUIAR, M. A. (Orgs.). A BNCC na contramão do PNE 2014-2024: avaliação e perspectivas. Recife: ANPAE, 2018, pp. 28-33.

OLIVEIRA, I. B. Políticas curriculares no contexto do golpe de 2016: debates atuais, embates e resistências. In: DOURADO, L. F.; AGUIAR, M. A. (Orgs.). A BNCC na contramão do PNE 2014-2024: avaliação e perspectivas. Recife: ANPAE, 2018, pp. 55-59.

OLIVEIRA, I. B.; SUSSEKIND, M. L. Dimensões político-epistemológicas do equívoco /conservador na educação: A base curricular brasileira no contexto dos currículos nacionais. Revista Portuguesa de Educação, num. 31, 2028, pp. 55-74.

RAVITCH, D. Vida e morte do grande sistema escolar americano: como os testes padronizados e o modelo de mercado ameaçam a educação. Porto Alegre: Sulina, 2011.

SANTOS, B. S. La incertidumbre: entre el miedo y la esperanza. In: GENTILI, P. \& TROTTA, N. (orgs.). América Latina: la democracia en la encrucijada. Buenos Aires: Editorial La Página S.A, 2016, pp. 161169.

TORRES, R. M. Derecho a la educación es mucho, mas que aceso de niños y ninãs a la escuela. Simposio Ciutat.edu: Nuevos retos, nuevos compromisos Barcelona, 2006.

\section{Correspondência}

Júlio César Augusto do Valle: É Doutor em Educação pela FE-USP e ex-Secretário Municipal de Educação e Cultura de Pindamonhangaba (SP, 2017-2020). Professor do Instituto de Matemática e Estatística da Universidade de São Paulo.

E-mail: juliio.valle@gmail.com

Texto publicado em Currículo sem Fronteiras com autorização do autor 